\title{
DEVELOPMENT AND VALIDATION OF AN RP-HPLC METHOD FOR THE DETERMINATION OF ULIPRISTAL ACETATE IN BULK AND PHARMACEUTICAL DOSAGE FORM
}

\author{
L SANATHOIBA SINGHA ${ }^{1 *}$, SREENIVAS RAO T ${ }^{2}$ \\ ${ }^{1}$ Rahman Institute of Pharmaceutical Sciences and Research, Guwahati, Assam, India. ${ }^{2}$ Department of Pharmaceutical Analysis, Karnataka \\ College of Pharmacy, Bengaluru, Karnataka, India. Email: azpro678@gmail.com
}

Received: 26 December 2020, Revised and Accepted: 16 February 2021

\section{ABSTRACT}

Objective: This work makes an attempt to establish a sensitive and accurate method for the development and validation of an analytical method for estimation of ulipristal acetate (UPA) in bulk and pharmaceutical dosage form.

Methods: A mixture of $20 \mathrm{mM}$ acetate buffer $\mathrm{pH} 3.7$ and methanol in the ratio of 70:30 (v/v \%) was used as the mobile phase. An xBridge ${ }^{\mathrm{TM}}$ C18 column $(250 \mathrm{~mm} \times 4.6 \mathrm{~mm}, 5 \mu)$ was used for the analysis at a flow rate of $1 \mathrm{ml} / \mathrm{min}$, injection volume of $20 \mu \mathrm{l}$, run time of $15 \mathrm{~min}$, and detection wavelength of $309 \mathrm{~nm}$. The repeatability (within-day in triplicates) and intermediate precision (for 2 days) were carried out by six injections and the obtained results within and between the days of trials were expressed as percent relative standard deviation (\% RSD). The linearity of the method was determined by the analysis of analyte concentration across a range of $10 \mu \mathrm{g} / \mathrm{ml}-60 \mu \mathrm{g} / \mathrm{ml}$.

Results: The \% RSD values of precision studies were found to be below the accepted limit of $2 \%$. The method was found to be linear with a correlation coefficient $\left(\mathrm{R}^{2}\right)$ of 0.98 . The method was also found to be accurate and robust with suitable values. Limit of detection (LOD) and limit of quantification (LOQ) of the method were found to be $0.371 \mu \mathrm{g} / \mathrm{ml}$ and $1.23 \mu \mathrm{g} / \mathrm{ml}$, respectively.

Conclusion: The results of analysis prove that this method can be used for the routine determination of UPA in bulk drug and in pharmaceutical dosage forms.

Keywords: Contraceptive, HPLC, Methanol, Signal to noise ratio, Ulipristal acetate, Uterine fibroids.

(C) 2021 The Authors. Published by Innovare Academic Sciences Pvt Ltd. This is an open access article under the CC BY license (http://creativecommons.org/ licenses/by/4.0/) DOI: http://dx.doi.org/10.22159/ajpcr.2021v14i4.40361. Journal homepage: https://innovareacademics.in/journals/index.php/ajpcr

\section{INTRODUCTION}

The most common benign gynecological tumors in women during reproductive years are uterine fibroids. Uterine fibroids are symptomatic in $20-40 \%$ of women [1]. However, a majority of women are asymptomatic and many uterine fibroids go undiagnosed [2]. Evidence suggests that they may arise by somatic mutation $[3,4]$. The indication of a genetic link can be understood from the fact that Caucasian women have a lower risk of developing fibroids than AfricanAmerican women [5,6]. Heavy menstrual bleeding, pelvic pressure and pain, reproductive dysfunction, and dysmenorrhea are the common symptoms [7-11]. The risk of infertility, miscarriage, premature deliveries, and complications in late pregnancy are higher in women with fibroids [12].

Various therapeutic approaches available for uterine fibroids include surgery, hormonal therapies, and radiological interventions [13]. A common procedure for complete removal of fibroids is hysterectomy. The disadvantage of this procedure is that it is not suitable for women who wish to retain fertility. Myomectomy is an alternative procedure for women who wish to retain fertility. However, myomectomy is associated with risks of adhesions, morbidity, and mortality in some cases [14]. Gonadotropin releasing hormone (GnRH) agonists (GnRHa) have been used to against amenorrhea and reduce fibroid size, but they are responsible for side effects such as bone mineral density loss and vasomotor symptoms. They are also responsible for rebound growth of the fibroids on cessation of therapy [15].

Selective progesterone modulators (SPRMs) are a new class of progesterone-receptor ligands that exert tissue-selective agonist, antagonist, or mixed agonist/antagonist activity in target cells [16]. Ulipristal acetate (UPA) is an SPRM that potently modulates progesterone receptor activity with pro-apoptotic or anti-proliferative effects on fibroid cells $[17,18]$. UPA possesses pharmacokinetic properties supporting once daily dosing [19]. In Europe, UPA is approved for treating fibroids [20,21]. It is also in clinical development for the treatment of ovarian and breast cancer $[22,23]$. UPA is also an oral emergency contraceptive indicated for the prevention of unintended pregnancy within $120 \mathrm{~h}$. UPA delays follicular maturation and ovulation [24]. UPA was approved in May 2009 by the European Commission for marketing as an emergency contraceptive $[25,26]$. The US FDA approved the drug for use in US on August 13, 2010 [27].

The IUPAC name of UPA is $[(8 S, 11 R, 13 S, 14 S, 17 R)$-17-acetyl-11-[4(dimethylamino)phenyl]-13-methyl-3-oxo-1,2,6,7,8,11,12,14,15,16decahydrocyclopenta[a]phenanthren-17-yl] acetate. It has a molecular formula of $\mathrm{C}_{30} \mathrm{H}_{37} \mathrm{NO}_{4}$ with a molecular weight of $475.6 \mathrm{~g} / \mathrm{mol}$. It is a white to yellowish crystalline powder. It has a strongest acidic $\mathrm{pK}_{\mathrm{a}}$ value of 12.7 and a strongest basic $\mathrm{pK}_{\mathrm{a}}$ value of 4.8 . It is freely soluble in dichloromethane, soluble in methanol, acetone and ethanol, and insoluble in water (Fig. 1) [28-30].

Reversed-phase high performance liquid chromatography (RP-HPLC) employs mainly dispersive forces (hydrophobic or Van der Waals interactions). The polarities of mobile and stationary phases are reversed, such that the surface of the stationary phase in RP HPLC is hydrophobic and mobile phase is polar, where mainly water-based solutions are employed. Literature survey has revealed only a few HPLC methods for estimation of UPA [31-32]. This work makes an attempt to develop a new sensitive and accurate RP-HPLC method for estimation of UPA in bulk and pharmaceutical dosage form and to validate the developed method in accordance with International Council on Harmonization of Technical Requirements for Registration of Pharmaceuticals for Human Use (ICH) guidelines [33]. 


\section{MATERIALS AND METHODS}

\section{Materials}

HPLC grade methanol and glacial acetic acid and sodium acetate were procured from Merck Life Science Private Limited, Mumbai, India. Direct- $\mathrm{Q}^{\circledR}$ Millipore was used for water purification. LC Compact 1120 HPLC system manufactured by Agilent Technologies was used for chromatographic analysis. EZ Chrome Elite software by Agilent Technologies was used for acquisition, evaluation, and storage of chromatographic data. A C18 column $(250 \mathrm{~mm} \times 4.6 \mathrm{~mm}, 5 \mu \mathrm{m})$ manufactured by $\mathrm{xBridge}^{\mathrm{TM}}$ was used as the column for HPLC. An ultra-sonication bath manufactured by Analab Scientific Instruments Private Limited, Vadodara, India, was used for degassing solutions. A vacuum pump and filtration kit manufactured by Superfit Continental Private Limited and Tarsons Products Private Limited, Kolkata, India, were used for filtering solutions. Nylon membrane filters $(0.45 \mu \mathrm{m})$ manufactured by Millipore (India) Private Limited were used in filtration.

Commercially available UPA tablets (5 $\mathrm{mg}$ ) were procured from local pharmacy, manufactured by Synokem Pharmaceuticals Ltd, Plot no. 56-57, Sector-6A, I. I. E. (SIDCUL), Ranipur (BHEL), Haridwar- 249403, Uttarakhand, India. UPA was obtained as a gift sample from Fortschritt Healthcare Ltd. Vill. Thana, Baddi, Dist. Solan (H.P.)- 173205, India.

\section{Methods}

Preparation of mobile phase

A mixture of $20 \mathrm{mM}$ acetate buffer $\mathrm{pH} 3.7$ and methanol in the ratio of $70: 30(\mathrm{v} / \mathrm{v} \%)$ was used as the mobile phase. Acetate buffer $\mathrm{pH} 3.7$ was prepared by dissolving $2 \mathrm{~g}$ of anhydrous sodium acetate in $300 \mathrm{ml}$ of water, adjusting the $\mathrm{pH}$ to 3.7 with glacial acetic acid and diluted with water to $1000 \mathrm{ml}$, and degassed in ultrasonic water for $10 \mathrm{~min}$ and vacuum filtered through $0.45 \mu \mathrm{m}$ filter.

\section{Preparation of standard stock solution}

A standard stock solution of concentration $1 \mathrm{mg} / \mathrm{ml}$ was prepared using the mobile phase as a diluent by taking $50 \mathrm{mg}$ of UPA in $50 \mathrm{ml}$ of volumetric flask. The solution is degassed in ultrasonic water for $10 \mathrm{~min}$ and vacuum filtered through $0.45 \mu \mathrm{m}$ filter.

\section{Preparation of working standard solution}

A working standard solution of concentration $10 \mu \mathrm{g} / \mathrm{ml}$ was prepared from the above stock solution using the mobile phase as a diluent.

\section{Preparation of sample stock solution}

A sample stock solution of concentration $1 \mathrm{mg} / \mathrm{ml}$ was prepared using the mobile phase as a diluent by taking an amount of sample equivalent to $50 \mathrm{mg}$ of UPA in $50 \mathrm{ml}$ of volumetric flask. The solution is degassed in ultrasonic water for $10 \mathrm{~min}$ and vacuum filtered through $0.45 \mu \mathrm{m}$ filter.

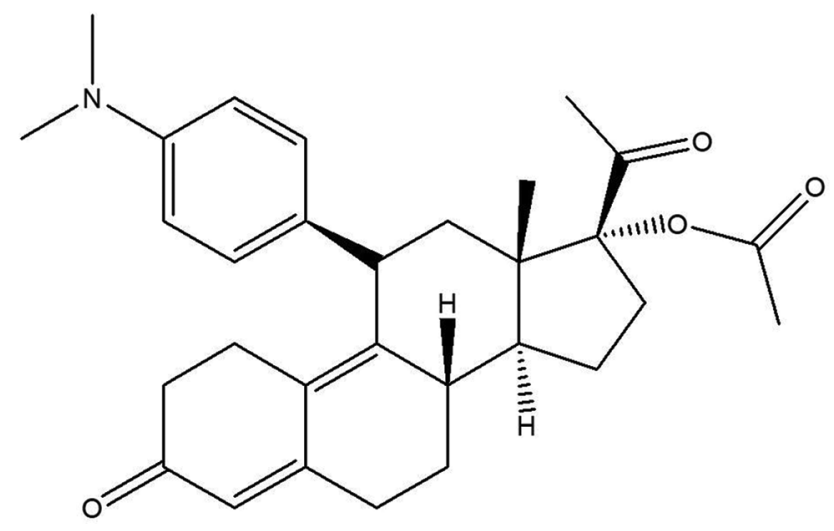

Fig. 1: Structure of UPA
Chromatographic conditions

xBridge $^{\mathrm{TM}}$ C18 column $(250 \mathrm{~mm} \times 4.6 \mathrm{~mm}, 5 \mu)$ was used for chromatographic analysis. The flow rate was set at $1 \mathrm{ml} / \mathrm{min}$ with a run time of $15 \mathrm{~min}$. The injection volume was $20 \mu \mathrm{l}$. The detector was set at a wavelength of $309 \mathrm{~nm}$.

\section{Precision}

Precision of the analytical method was studied by analysis of multiple sampling of homogeneous sample. Method reproducibility was demonstrated by repeatability and intermediate precision measurements of peak area and peak symmetry parameters. The repeatability (within-day in triplicates) and intermediate precision (for 2 days) were carried out at single concentration level. Six injections were made and the obtained results within and between the days of trials were expressed as \% RSD [34].

\section{Linearity}

Linearity of the method was determined by the analysis of analyte concentration across a range of $10 \mu \mathrm{g} / \mathrm{ml}$ to $60 \mu \mathrm{g} / \mathrm{ml}$ of UPA and area was plotted graphically as a function of analyte concentration [35].

\section{Accuracy}

A recovery experiment of UPA was used to find the accuracy of the developed method. Accuracy of the method was determined by calculating recoveries of UPA by the standard addition method. In prequantified sample solution $(40 \mu \mathrm{g} / \mathrm{ml})$, a known amount of standard solutions of UPA $(80 \%, 100 \%$, and $120 \%)$ were added. The quantity of UPA was measured using a calibration curve [36].

\section{Robustness}

Robustness of the method was studied by deliberate changes in the method such as alteration of flow rate and wavelength of detection [37].

\section{Limit of detection (LOD) and limit of quantification (LOQ)}

LOD and LOQ were calculated according to ICH recommendations where the approach is based on the signal-to-noise ratio. A signal to noise ratio 3:1 and 10:1 was considered for calculating LOD and LOQ respectively [38].

\section{Statistical analysis}

Result for linearity was calculated using linear regression in Microsoft Excel 2010 software package for Windows operating system. The \% RSD was calculated for all values.

\section{RESULTS AND DISCUSSION}

System suitability test was applied to the chromatograms taken under optimum conditions to check various parameters such as theoretical

Table 1: System suitability testing (UPA $10 \mu \mathrm{g} / \mathrm{ml}$ )

\begin{tabular}{llll}
\hline $\begin{array}{l}\text { Theoretical } \\
\text { plates (USP) }\end{array}$ & $\begin{array}{l}\text { Capacity } \\
\text { factor }\end{array}$ & $\begin{array}{l}\text { Asymmetry } \\
\text { (Tailing factor) }\end{array}$ & S/N (6 o) \\
\hline 7093 & 0.00256 & 1.16184 & 80.746819 \\
\hline
\end{tabular}

Table 2: Interday precision

\begin{tabular}{llll}
\hline S. No. & Sample & Peak area & \\
\cline { 3 - 4 } & & Day 1 & Day 2 \\
\hline 1 & Sample 1 & 5694116 & 5698077 \\
2 & Sample 2 & 5673333 & 5748510 \\
3 & Sample 3 & 5786536 & 5759750 \\
4 & Sample 4 & 5659659 & 5651528 \\
5 & Sample 5 & 5764871 & 5750448 \\
6 & Sample 6 & 5684321 & 5625445 \\
Average & & 5710472 & 5705626 \\
SD & & 47710.31 & 56903.48 \\
$\%$ RSD & & 0.91 & 0.99 \\
\hline
\end{tabular}




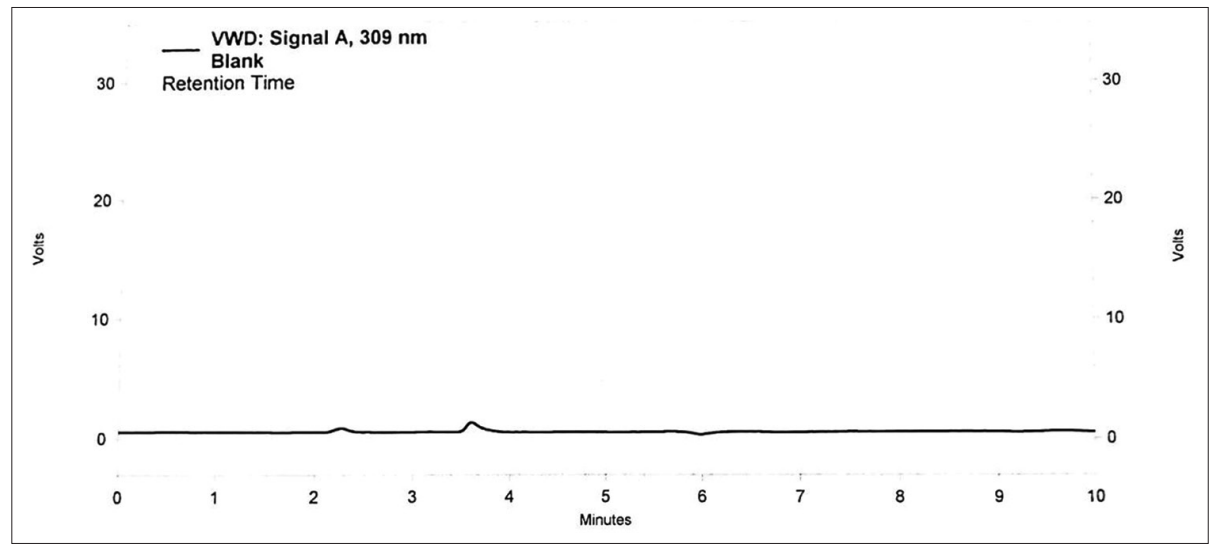

Fig. 2: Chromatogram of blank

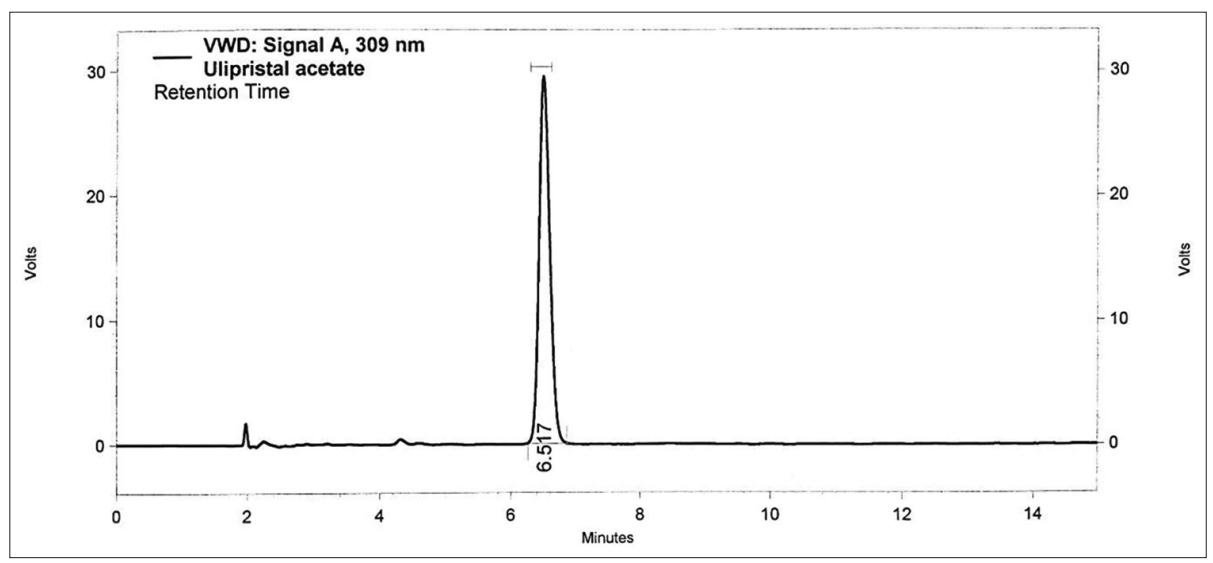

Fig. 3: Chromatogram of UPA $(10 \mu \mathrm{g} / \mathrm{ml})$

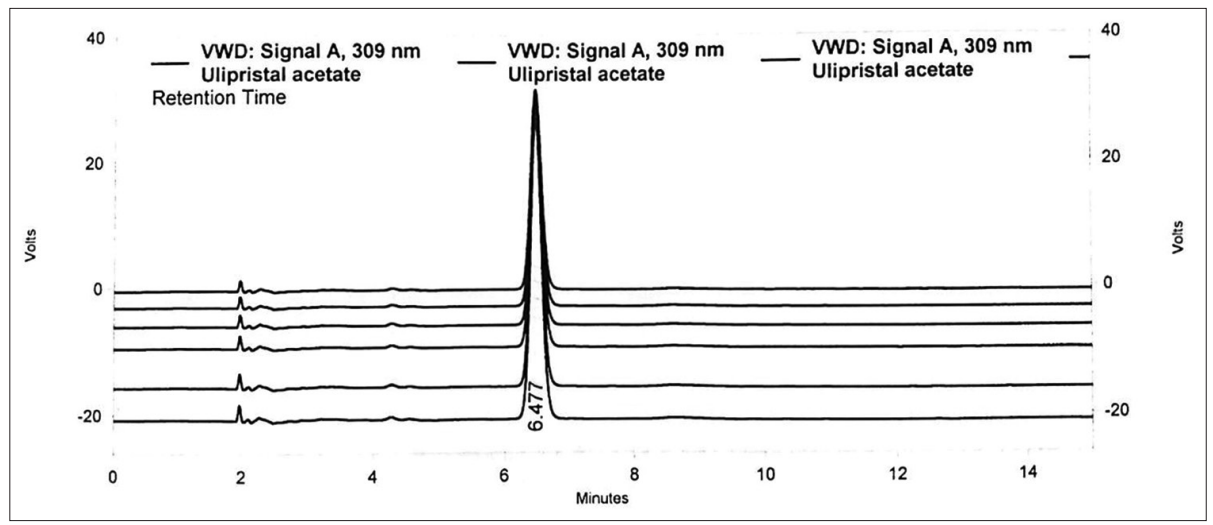

Fig. 4: Chromatogram showing interday precision (day 1)

Table 3: Intraday precision

\begin{tabular}{|c|c|c|c|}
\hline \multirow[t]{2}{*}{ S. No. } & \multirow[t]{2}{*}{ Sample } & \multicolumn{2}{|l|}{ Peak area } \\
\hline & & Morning & Afternoon \\
\hline 1 & Sample 1 & 5765465 & 5634645 \\
\hline 2 & Sample 2 & 5656463 & 5765161 \\
\hline 3 & Sample 3 & 5565983 & 5623165 \\
\hline 4 & Sample 4 & 5732137 & 5749496 \\
\hline 5 & Sample 5 & 5689915 & 5589451 \\
\hline 6 & Sample 6 & 5729897 & 5634969 \\
\hline Average & & 5689976 & 5666147 \\
\hline SD & & 71508.34 & 72725.51 \\
\hline$\%$ RSD & & 1.25 & 1.28 \\
\hline
\end{tabular}

Table 4: Linearity at a concentration range of $10-60 \mu \mathrm{g} / \mathrm{ml}$

\begin{tabular}{lll}
\hline S. No. & Concentration $(\boldsymbol{\mu g} / \mathbf{m l})$ & Peak area \\
\hline 1 & 10 & 6184017 \\
2 & 20 & 11246065 \\
3 & 30 & 26468955 \\
4 & 40 & 36459950 \\
5 & 50 & 48973542 \\
6 & 60 & 64254917 \\
\hline
\end{tabular}

plates, capacity factor, asymmetry, and signal-to-noise ratio (Figs. 2 and 3). Suitable tests results were achieved for the proposed method. All these results indicate the suitability of the instrument for the developed method (Table 1). 


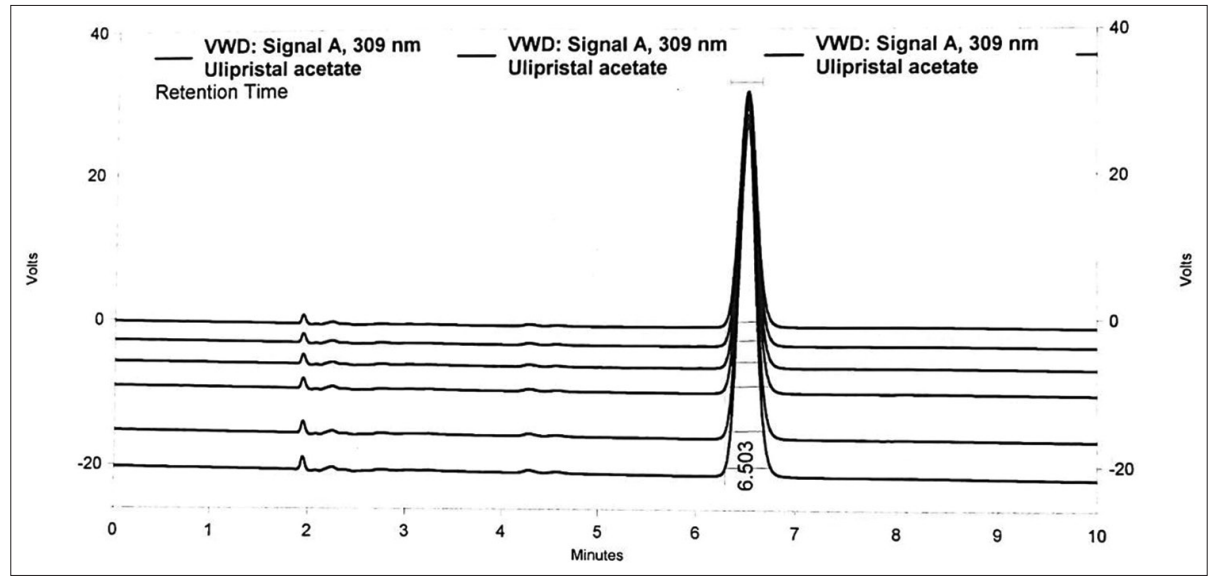

Fig. 5: Chromatogram showing interday precision (day 2)

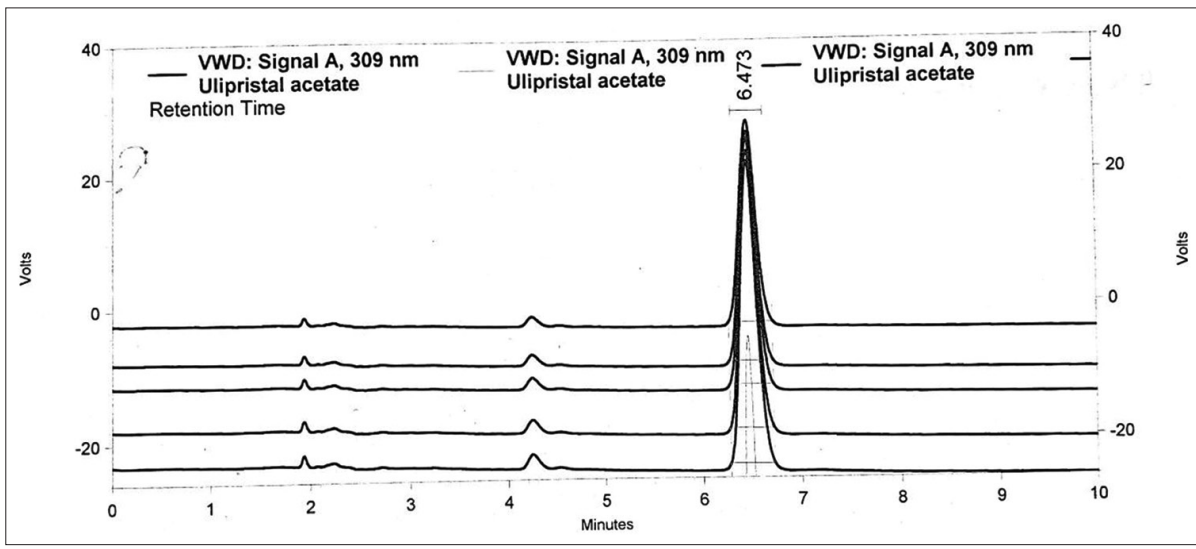

Fig. 6: Chromatogram showing intraday precision (morning)

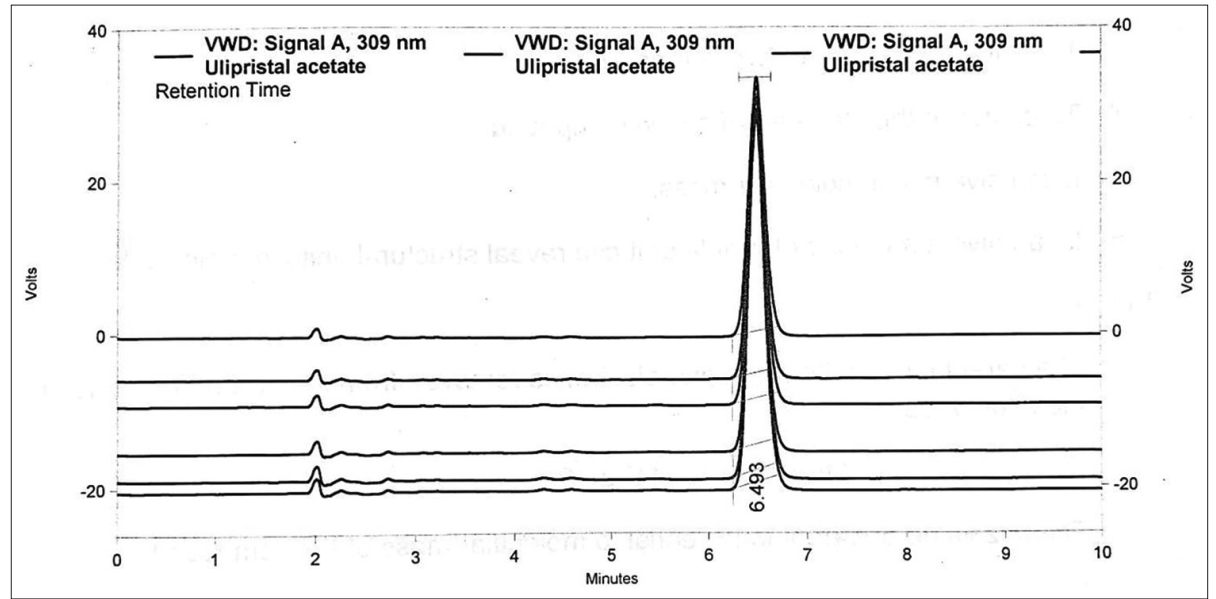

Fig. 7: Chromatogram showing intraday precision (afternoon)

Table 5: Data for accuracy

\begin{tabular}{|c|c|c|c|c|c|c|}
\hline S. No. & Spike level (\%) & $\begin{array}{l}\text { Amount of drug in } \\
\text { pre-quantified sample }(\mu \mathrm{g} / \mathrm{ml})\end{array}$ & $\begin{array}{l}\text { Conc. of standard } \\
\text { addition }(\mu \mathrm{g} / \mathrm{ml})\end{array}$ & Sample & Recovery (\%) & Mean \% recovery \\
\hline \multirow[t]{3}{*}{1} & 80 & 40 & 32 & Sample 1 & 98.75 & 98.85 \\
\hline & & & & Sample 2 & 99.4 & \\
\hline & & & & Sample 3 & 98.4 & \\
\hline \multirow[t]{3}{*}{2} & 100 & 40 & 40 & Sample 1 & 99 & 99.42 \\
\hline & & & & Sample 2 & 99.5 & \\
\hline & & & & Sample 3 & 98.75 & \\
\hline \multirow[t]{3}{*}{3} & 120 & 40 & 48 & Sample 1 & 99.58 & 99.37 \\
\hline & & & & Sample 2 & 99.16 & \\
\hline & & & & Sample 3 & 99.38 & \\
\hline
\end{tabular}


For study of precision six replicates of the standard solution was injected into the HPLC system in interday and intraday intervals. The

Table 6: Data for robustness

\begin{tabular}{lllll}
\hline S. No. & Parameter & Conditions & $\begin{array}{l}\text { Retention } \\
\text { time (min) }\end{array}$ & $\begin{array}{l}\text { Peak } \\
\text { area }\end{array}$ \\
\hline 1. & Flow rate & $0.9 \mathrm{ml}$ & 7.22 & 7039434 \\
& & $1 \mathrm{ml}$ & 6.52 & 5548510 \\
& & $1.1 \mathrm{ml}$ & 5.92 & 5635388 \\
2. & Detection & $300 \mathrm{~nm}$ & 6.53 & 6154044 \\
& wavelength & $309 \mathrm{~nm}$ & 6.52 & 5548150 \\
& & $318 \mathrm{~nm}$ & 6.53 & 5094870 \\
\hline
\end{tabular}

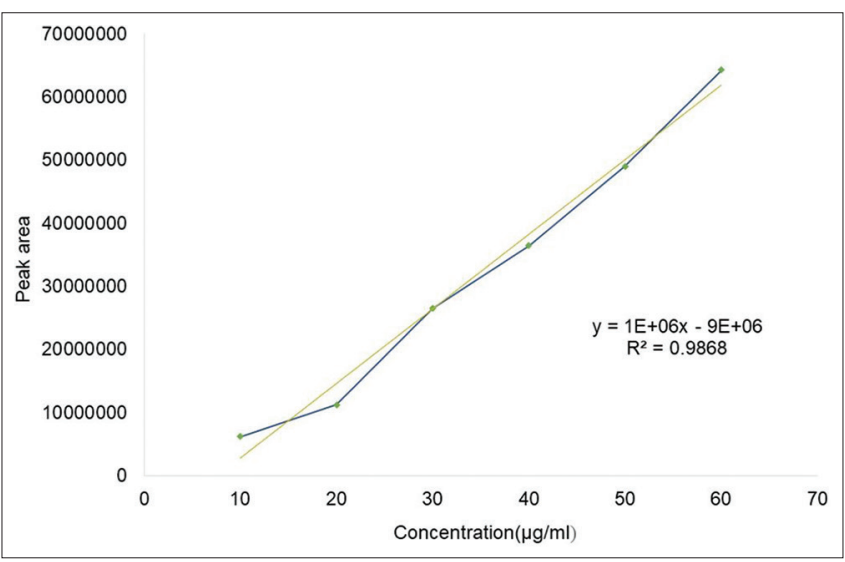

Fig. 8: Linearity graph for UPA $(10-60 \mu \mathrm{g} / \mathrm{ml})$
$\%$ RSD values of day 1 and day 2 for interday intervals were found to be $0.91 \%$ and $0.99 \%$, respectively (Figs. 4 and 5), while the $\%$ RSD values of morning and afternoon sessions for intraday intervals were found to be $1.25 \%$ and $1.28 \%$, respectively (Figs. 6 and 7). Therefore, the $\%$ RSD values for precision studies are within the accepted limits if $2 \%$ (Tables 2 and 3).

Linearity was performed using standard solutions in the concentration range of 10-60 $\mu \mathrm{g} / \mathrm{ml}$ (Table 4). Calibration curve was constructed for the standards by plotting the concentrations versus peak areas and evaluated by linear regression analysis. The correlation coefficient $\left(\mathrm{R}^{2}\right)$ was found to be 0.98 , which is within the accepted limits (Fig. 8).

Accuracy was performed by spiking a pre-quantified sample with standard at $80 \%, 100 \%$, and $120 \%$ (Fig. 9) (Figs. 10 and 11). The solutions were prepared in triplicates and analyzed through the developed method. The mean recovery values of obtained for the three trials were $98.85 \%, 99.42 \%$, and $99.37 \%$, respectively, which indicates that there is an extremely less interference coming from matrix components (Table 5).

For robustness a change of $\pm 0.1 \mathrm{ml} / \mathrm{min}$ in the optimized flow rate of $1 \mathrm{ml} / \mathrm{min}$ of the method was done, resulting in the change of retention time from $6.52 \mathrm{~min}$ to $7.22 \mathrm{~min}$ and $5.92 \mathrm{~min}$, respectively, for each deliberate change in flow rate. Similarly, a change of $\pm 9 \mathrm{~nm}$ in the optimized detection wavelength of $309 \mathrm{~nm}$ of the method was done, resulting in the change of retention time from $6.52 \mathrm{~min}$ to $6.53 \mathrm{~min}$ and $6.53 \mathrm{~min}$, respectively, for each deliberate changes (Table 6).

Considering the accepted limits for signal to noise ratio of $3: 1$ and 10:1 for calculating LOD and LOQ, respectively, the LOD and LOQ of the method was found to be $0.371 \mu \mathrm{g} / \mathrm{ml}$ and $1.23 \mu \mathrm{g} / \mathrm{ml}$, respectively.

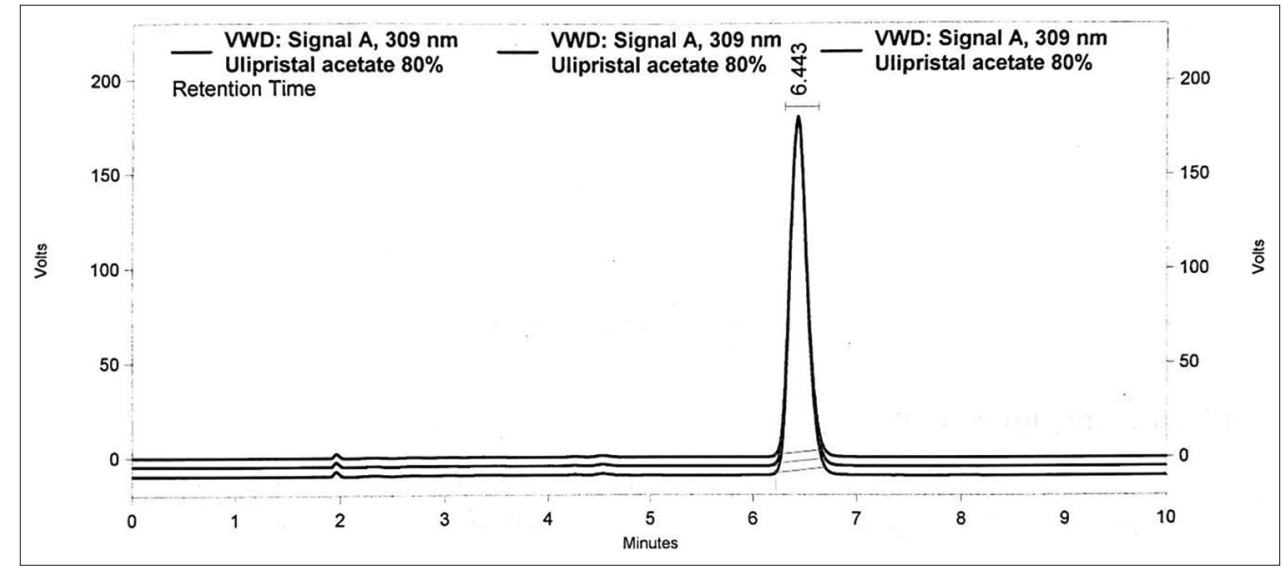

Fig. 9: Chromatogram for accuracy (80\%)

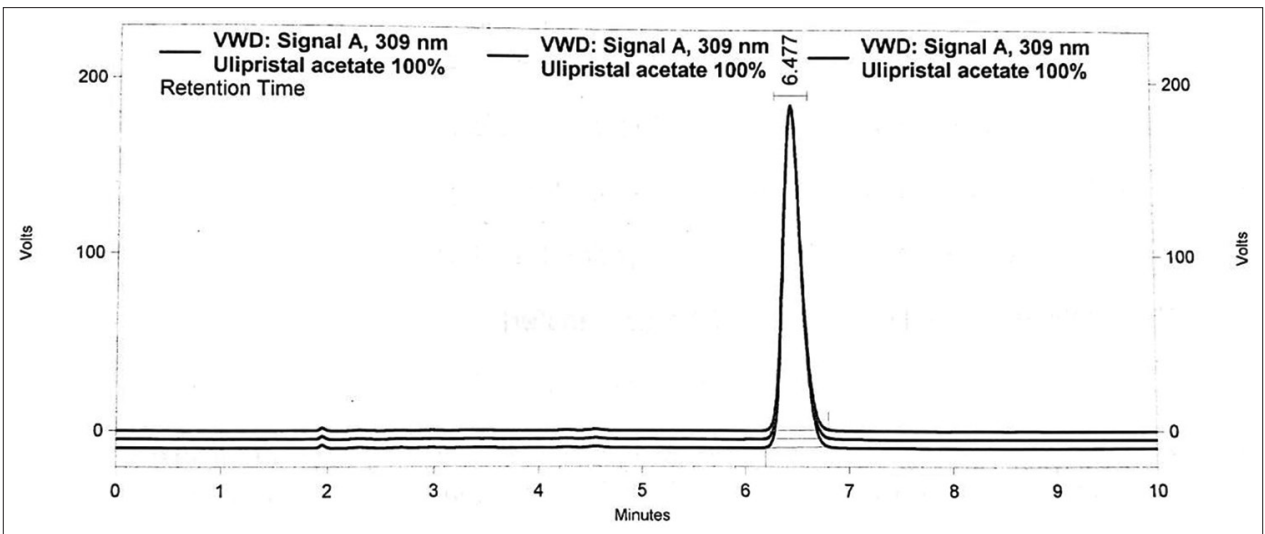

Fig. 10: Chromatogram for accuracy (100\%) 


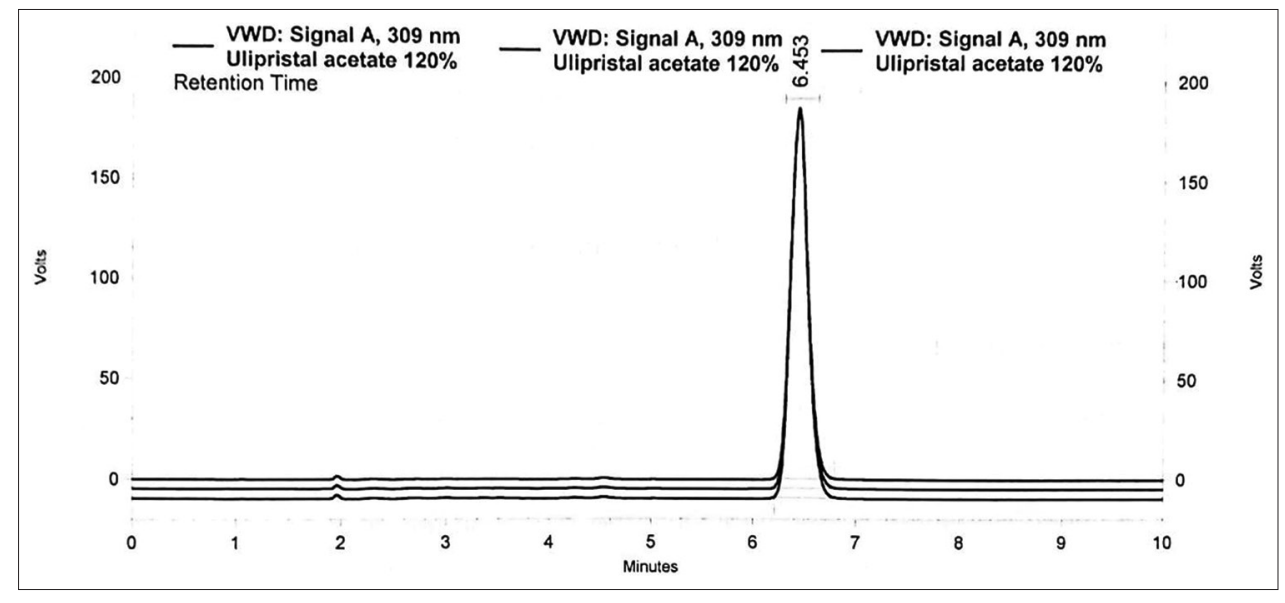

Fig. 11: Chromatogram for accuracy (120\%)

\section{CONCLUSION}

The proposed method showed acceptable accuracy, precision, linear concentration range, and robustness. The results of analysis proved that the method is suitable for the determination of UPA in bulk and tablet dosage form without any interference from its excipients and this method can be used for the routine determination of UPA in bulk drug and in pharmaceutical dosage forms.

\section{ACKNOWLEDGMENT}

The authors are indebted to Karnataka College of Pharmacy, Bengaluru 560064, Karnataka, India, for providing the facilities to carry out the research work described in this paper.

\section{AUTHOR'S CONTRIBUTIONS}

L Sanathoiba Singha performed the study and prepared the manuscript. Sreenivas Rao T supervised the study and reviewed the data.

\section{CONFLICT OF INTERESTS}

The authors have no conflict of interests.

\section{AUTHOR'S FUNDING}

The authors did not receive any funding for this work from any organization.

\section{REFERENCES}

1. Hoellen F, Griesinger G, Bohlmann MK. Therapeutic drugs in the treatment of symptomatic uterine fibroids. Expert Opin Pharmacother 2013:14:2079-85

2. Buttram VC Jr., Reiter RC. Uterine leiomyomata: Etiology, symptomatology, and management. Fertil Steril 1981:36:433-45.

3. Rein MS, Friedman AJ, Barbieri RL, Pavelka K, Fletcher JA, Morton CC. Cytogenetic abnormalities in uterine leiomyomata. Obstet Gynecol 1991;77:923-6.

4. Mashal RD, Fejzo ML, Friedman AJ, Mitchner N, Nowak RA, Rein MS, et al. Analysis of androgen receptor DNA reveals the independent clonal origins of uterine leiomyomata and the secondary nature of cytogenetic aberrations in the development of leiomyomata. Genes Chromosomes Cancer 1994:11:1-6.

5. Ligon A, Morton C. Leiomyomata: Heritability and cytogenetic studies. Hum Reprod Update 2001;7:8-14.

6. Baird DD, Dunson DB, Hill MC, Cousins D, Schectman JM. High cumulative incidence of uterine leiomyoma in black and white women: Ultrasound evidence. Am J Ostet Gynecol 2003;188:100-7.

7. Philipp CS, Faiz A, Heit JA, Kouides PA, Lukes A, Stein SF, et al. Evaluation of a screening tool for bleeding disorders in a US multisite cohort of women with menorrhagia. Am J Obstet Gynecol 2011;204:209.

8. Zakherah MS, Sayed GH, El-Nashar SA, Shaaban MM. Pictorial blood loss assessment chart in the evaluation of heavy menstrual bleeding:
Diagnostic accuracy compared to alkaline hematin. Gynecol Obstet Invest 2011;71:281-4

9. Melis GB, Piras B, Marotto MF, Orru MM, Maricosu G, Pilloni M, et al. Pharmacokinetic evaluation of ulipristal acetate for uterine leiomyoma treatment. Expert Opin Drug Metab Toxicol 2012;8:901-8.

10. Donnez J, Jadoul P. What are the implications of myomas on fertility? A need for a debate? Hum Reprod 2002;17:1424-30.

11. Practice Committee of American Society for Reproductive Medicine in Collaboration with Society of Reproductive Surgeons. Myomas and reproductive function. Fertil Steril 2008;90:S125-30.

12. Donnez J, Jadoul P. What are the implications of myomas on fertility? A need for a debate? Hum Reprod 2002;17:1424-30.

13. Tafi E, Scala C, Maggiore UL, Bizzarri N, Candiani M, Venturini PL, et al. Drug safety evaluation of ulipristal acetate in the treatment of uterine fibroids. Expert Opin Drug Saf 2015;14:965-77.

14. McCarthy-Keith DM, Armstrong AY. Innovations in uterine fibroid therapy. Therapy 2011;8:189-200.

15. Talaulikar VS, Belli AM, Manyonda I. GnRH agonists: Do they have a place in the modern management of fibroid disease? J Obstet Gynecol India 2012;62:506-10

16. Chwalisz K, Perez MC, DeManno D, Winkel C, Schubert G, Elger W. Selective progesterone receptor modulator development and use in the treatment of leiomyomata and endometriosis. Endocr Rev 2005;26:423-38.

17. Gainer EE, Ulmann A. Pharmacologic properties of CDB(VA)-2914. Steroids 2003;68:1005-11

18. Horak P, Mara M, Dundr P, Kubinova K, Kuzel D, Hudecek R, et al. Effect of a selective progesterone receptor modulator on induction of apoptosis in uterine fibroids in vivo. Int J Endocrinol 2012;2012:436174.

19. Pohl O, Osterloh I, Gotteland JP. Ulipristal acetate - safety and pharmacokinetics following multiple doses of 10-50 mg per day. J Clin Pharm Ther 2013;38:314-20.

20. Donnez J, Tatarchuk TF, Bouchard P, Puscasiu L, Zakharenko NF, Ivanova $\mathrm{T}$, et al. Ulipristal acetate versus placebo for fibroid treatment before surgery. N Engl J Med 2012;366:409-20.

21. Biglia N, Carinelli S, Maiorana A, D’Alonzo M, Lo Monte G, Marci R. Ulipristal acetate: A novel pharmacological approach for the treatment of uterine fibroids. Drug Des Dev Ther 2014;8:285-92.

22. Chabbert-Buffet N, Meduri P, Bouchard G, Spitz IM. Selective progesterone receptor modulators and progesterone antagonists: Mechanisms of action and clinical applications. Hum Reprod Update 2005;11:293-307.

23. Goyeneche AA, Seidel EE, Telleria CM. Growth inhibition induced by antiprogestins RU-38486, ORG-31710, and CDB-2914 in ovarian cancer cells involves inhibition of cyclin dependent kinase 2. Invest New Drugs 2012;30:967-80

24. Chabbert-Buffet N, Ouzounian S, Kairis A, Bouchard P. Contraceptive applications of progesterone receptor modulators. Eur J Contracept Reprod Health Care 2008;13:222-30.

25. Cunningham F, Leveno K, Bloom S, Hauth J, Rouse D, Spong C. Williams Obstetrics. Vol. 23. New York: McGraw-Hill Professional; 2010. p. 692-4

26. Emma H. FDA Panel Gives UPA Unanimous Positive Vote for Emergency Contraception Indication. New York: Medscape Medical News; 2010. Available from: http://www.medscape.com/ viewarticle/723822. [Last accessed on $2020 \mathrm{Feb} 03]$. 
27. Richardson AR, Maltz FN. Ulipristal acetate: Review of the efficacy and safety of a newly approved agent for emergency contraception. Clin Ther 2011;34:24-36.

28. National Center for Biotechnology Information. PubChem Compound Summary for CID 130904, UPA. Available from: https://www.pubchem. ncbi.nlm.nih.gov/compound/Ulipristal-acetate. [Last accessed on 2020 Feb 05].

29. Ulipristal, Drug Bank. Available from: https://www.drugbank.ca/drugs/ DB08867. [Last accessed on 2020 Feb 05]

30. ERA Consulting. AusPAR Attachment 1: Product Information for UPA. Available from: https://www.tga.gov.au/sites/default/files/ausparulipristal-acetate-161019-pi.docx\#: :text=Ulipristal\%20acetate $\% 20$ is $\% 20 \mathrm{a} \% 20$ white, ethanol $\% 20$ and $\% 20$ insoluble $\% 20$ in $\% 20$ water. [Last accessed on 2020 Feb 05].

31. Jin-Xiao S, Feng-Yan Z, Qiao-Gen Z, Li-Ii S, Ping W. Determination of UPA and its related substances by HPLC. Chin J New Drugs 2014;7:839-42.

32. Rao AL, Alimunnisa, Tejaswini DS, Lakshmi GLVJ, Vani VBN. Development and validation of stability indicating HPLC method for the determination of UPA in pharmaceutical dosage form. Int J Res Ayush Pharm Sci 2019;3:321-7.
33. Validation of Analytical Procedures: Text and Methodology Q2(R1). International Conference on Harmonisation of Technical Requirements for Registration of Pharmaceuticals for Human Use. Available from: https://www.database.ich.org/sites/default/files/Q2\%28R1\%29\%20 Guideline.pdf. [Last accessed on 2020 Feb 08].

34. Narasimhan B, Abida K, Srinivas K. Stability indicating RP-HPLC method development and validation for oseltamivir API. Chem Pharm Bull 2008;56:413-7.

35. Sreekanth N, Rao CB, Mukkanti K. RP-HPLC method development and validation of ropinirole hydrochloride in bulk and pharmaceutical dosage forms. Int J Pharm Pharm Sci 2009; 1:186-92.

36. Swamy GK, Rao JV, Kumar JM, Kumar UA, Bikshapathi DV, Kumar DV. Analytical method development and validation of aliskiren in bulk and tablet dosage form by RP- HPLC method. J Pharm Res 2011;4:865-7.

37. Debata J, Kumar S, Jha SK, Khan A. A new RP-HPLC method development and validation of dapagliflozin in bulk and tablet dosage form. Int J Drug Dev Res 2017;9:48-51.

38. Çelebier M, Reçber T, Koçak E, Altınöz S. RP-HPLC method development and validation for estimation of rivaroxaban in pharmaceutical dosage forms. Braz J Pharm Sci 2013;49:359-66. 